\title{
The strophic structure of the eulogy of Ephesians 1:3-14
}

\author{
J H Barkhuizen \\ University of Pretoria
}

\begin{abstract}
The strophic structure of the eulogy of Ephesians 1:3-14

Since Eduard Norden's (1913) statement concerning the awkward length and construction of Ephesians 1:3-14, a flood of studies have been devoted to the analysis of this Greek sentence. In this paper I have firstly given an overview of those studies representative of the structure of the eulogy of Ephesians 1:3-14, and secondly presented a new reconstruction of this passage based on principles of form and content.
\end{abstract}

\section{INTRODUCTION}

The existence of hymns or hymnic fragments in the New Testament is a common and accepted fact among New Testament scholars and hymnologists. These hymns or hymnic fragments have been divided by Martin (1982:789-790; 1983:132-133) into three categories: The Lucan canticles, the hymns in the Revelation, and specific Christian hymns. To this last category belong most of the hymns and hymnic fragments in the New Testament. Some of these specific Christian hymns can either be distinguished clearly from their context, for example Philippians 2:6-11 and 1 Timothy 3:16, or are woven into the text, for example the hymn in the prologue of the Gospel of John (1:1-18) and the eulogy of Ephesians 1:3-14.

It is important to note in this regard that no hymn or hymnic fragment in the New Testament has been 'arranged' (whether the hymn has been 'quoted' or 'reworked') into specific strophes by the particular author. This has led to many endeavours on the part of various scholars to reconstruct such strophes, with the result that one is reminded of the well-known Latin idiom: Quot homines, tot sententiae! Although these reconstructions remain speculative there seems to be a never-ending flow of articles intent on establishing yet another 'strophic' structure for these hymns. 
Seeing that this article presents another such an attempt, it would seem necessary to pose the question of whether it is of any importance to establish strophic structures for these hymns. I believe, in conjunction with several important New Testament scholars, that this question must be answered in the affirmative. It is, in fact, of both exegetical and liturgical importance: These hymns were woven into their present contexts not merely for an aesthetical reason, but they are closely related to the thought sequence of the particular passage or text as a whole. Thus Krämer (1967:35) states: 'Die Exegese wird nämlich bei einem so bewusst formulierten Text nie [italics mine] von der stilistischen Formen absehen können; darum hängt von ihrem richtigen Verstăndnis einiges ab'. Louw (1989:41) has also shown that the hymn in the prologue of the Gospel of John contains key motives anticipating the theme of the Gospel as a whole. Also of importance is the following statement in regard to Ephesians 1:3-14:

...so ist doch nicht zu besweifeln, dass mit der Unterscheidung von Tradition und Interpretation auch für die Auslegung der Briefe eine wichtige und fruchtbare Betrachtungsweise gefunden ist. Bereits Paulus hat sicher vorgeprägte Traditionen aufgenommen und für seine theologischen Argumentationen ausgewertet....

(Lang 1969:7)

In the case of Ephesians 1:3-14 this is of significance, since this eulogy is seen by many scholars as the key to the letter as a whole (exegetical aspect, e g Maurer 1951/2; Krämer 1967; Schnackenburg 1977), as well as the fact that it is most probably related to a baptismal ritual (liturgical aspect, e g Coutts 1956/7; Lang 1969).

It goes without saying that the reconstruction of these hymns cannot be realised without taking into account the strophic principles involved. Several important studies have been published in this regard, that of Norden [1913](1956) having exerted considerable influence. Of recent importance are the studies of Van der Lugt (1980) and Watson (1986) on Old Testament poetry, and Gloer (1984) on New Testament hymns. However, these principles have also been identified and applied to specific hymns in several other studies on the subject. In general one may distinguish two main categories of strophic principles:

* Those related to content; 
- Those related to form: grammatical, syntactical and stylistic-rhetorical elements, as well as formal hymnic elements (metre, refrain, acrostic, etc).

It is important to note that these categories are to be seen in a complementary sense, and that they should not be applied in isolation. Where this one-sided approach has been followed, well-founded criticism has not remained behind. This has also happened in the case of the reconstruction of the eulogy in Ephesians 1:314 (see Lang 1969:8).

\section{FIVE IMPORTANT APPROACHES TO THE STRUCTURE OF EPHESIANS 1:3-14}

The presence of hymnic or liturgical elements in the first three chapters of the letter to the Ephesians has been widely acknowledged, even by those who reject the idea of a hymn in Ephesians 1:3-14 (e g Sanders 1965; Deichgräber 1967:72; Gnilka 1971:60; Conzelmann 1976:90; Schnackenburg 1977:68, 69,75). Not only does this opening section begin with a doxology or eulogy $(1: 3 a)$, but it also concludes with one (3:21). In the light of the liturgical character of the opening chapters, the instruction of the author in 5:19 gains in significance: 'speak to one another in psalms, hymns and songs; sing and make music in your hearts to the Lord' (NEB).

Since the study of Innitzer (1904) various analyses have been attempted at reconstructing the 'hymn' in 1:3-14. According to Schnackenburg (1977:67-68), they can all be divided into three groups:

- Those who maintain that the author has taken elements from an original hymn and reworked them into the first three chapters or into 1:3-14;

- Those who maintain that $1: 3-14$ is in fact a 'quoted' hymn (i e taken directly from the liturgy into its present context);

* Those who follow the opinion of the first group, and who have subsequently tried to reconstruct the 'original' hymn.

As to the type of 'hymn' or 'hymnic fragment present in 1:3-14, 1:3 clearly characterises it as eulogy (see also 2 Cor 1:3 and $1 \mathrm{Pt}$ 1:3), based on the Jewish Berakah or the Hodajot from the Qumran community (see especially Audet 1958; Deichgräber 1967; Robinson 1964; Maier 1972; Schnackenburg 1977:68). This type of 'genre' consists of two basic elements: (a) God is addressed in the third person, often defined by appositions; This is followed by (b) a 'body', naming and espanding upon the reason(s) for the eulogy, often referring to God's salvific acts towards his 
people (Israel or the Jews) or the Christian community.

In the following overview I have selected the five most important approaches to the structure of this eulogy. This will be followed in paragraph 3 by a reconstruction by the present author.

\subsection{Cambier: The trinitarian theory}

Cambier (1963) has presented a fairly detailed analysis of the passage, taking both categories of principles into consideration, namely a formal as well as a logicalexegetical principle. The main formal aspect on which his structure is based is the

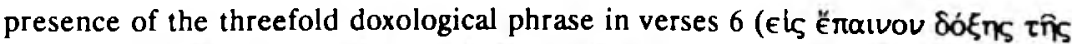

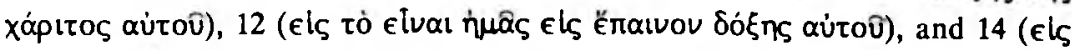

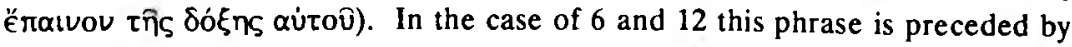

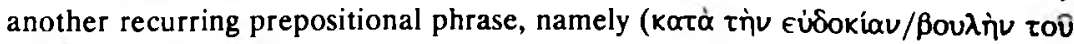
$\theta \in \lambda$ injatos aúrov̂). These phrases, then, serve as markers of the strophic division of the passage. Cambier also lists as an important formal element the prepositional

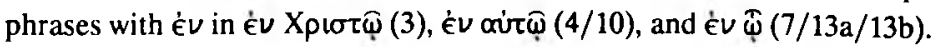

In addition to these formal elements, Cambier resorts to a logical division consisting of a trinitarian scheme. His overall structure is as follows:
Introduction:
$1: 3$
$=$ the eulogy
First strophe:
$1: 4-6$
$=$ God's adoption of us
Second strophe:
$1: 7-12$
= our salvation through Christ
Final strophe:
$1: 13-14$
= sanctification through the Holy Spirit.

In a South African context the representations of both Roberts (1983:27-44) and Louw (1987) correspond to the structure suggested by Cambier.

Two points of criticism often brought in against this division, and which certainly bear weight, are (a) the asymmetrical division thus established (i e a too long second strophe, 7-12; see Bouwman 1974:26), which is neccessitated by (b) the rigid application of a trinitarian scheme.

\subsection{Schattenmann: The isometric theory}

Although the reconstruction of Schattenmann (1965:1-10), followed by that of Mitsakis (1986), has exerted little influence, it merits a separate discussion. He presents us with the following structure: 


$\begin{array}{ll}\text { 'Überschrift': } & 3 \mathrm{a} \\ \text { First strophe: } & 3 \mathrm{~b}-5 \mathrm{a} \\ \text { Refrain: } & 5 \mathrm{~b}-6 \mathrm{a} \\ \text { Second strophe: } & 6 \mathrm{~b}-9 \mathrm{a} \\ \text { Refrain: } & 9 \mathrm{~b}-10 \mathrm{a} \\ \text { 'Mittelschrift': } & 10 \mathrm{~b} \\ \text { Third strophe: } & 11 \\ \text { Refrain: } & 12 \\ \text { Fourth strophe: } & 13-14 \mathrm{a} \\ \text { Refrain: } & 14 \mathrm{~b} .\end{array}$

Three principles are involved in this structure:

- An isometric principle, which forms the main dividing principle. This is based on the change within the Greek language from a quantative metre (long + short) to a rhythmical metre (accented + unaccented). With the inclusion of the refrain, strophe 1 has 60 words and 136 syllables; strophe 2 consists also of 60 words and 136 syllables; strophe 3 has 40 words with 77 syllables; and strophe 4 also 40 words but 92 syllables.

* The refrain. It is to be noted, however, that Schattenmann takes the phrase

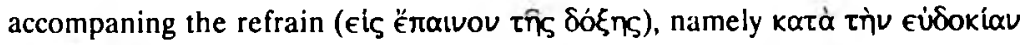
aivou as the refrain of the second strophe.

- Theme. At the beginning of each strophe the author places three 'Verbalgriffe' (Schattenmann 1965:3) for emphasis, which at the same time introduce the theme of the strophe. In strophe 1 they are: $\epsilon \dot{U} \lambda o \gamma \eta \dot{\sigma} \sigma \alpha, \dot{\epsilon} \pi \epsilon \lambda \epsilon \xi \alpha \tau$,

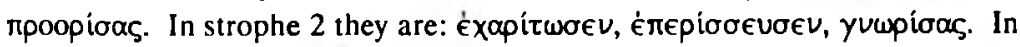

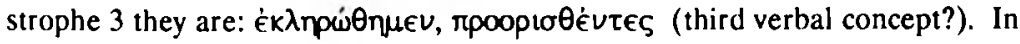

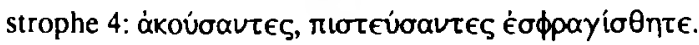

Two points of criticism may be put forward against Schattenmann's structure:

* His division of strophes completely cuts across the syntactical structure and logical sequence of thought (see also Krämer 1967:37).

- His method of counting syllables within the rhythmical pattern of the language is quite arbitrary and does not comply with the principles of rhythmical poetry. In the well-defined rhythmical poetry of the fifth century and onwards, the basis of this metre is isosyllaby and homotony: Each corresponding line of each strophe has the same number of syllables (isosyllaby) accented in each case on 
the identical syllable in each line of each strophe (homotony). These principles are totally ignored by Schattenmann. Although each strophe in the end may contain the same number of syllables (which in the case of elision and hiatus becomes improbable), there must always be a demonstrable inner correspondence, as I have outlined above. Krämer (1967:37) has therefore rightly referred to this theory as 'Zahlenspielerei'.

\subsection{Krämer: The formulaic theory}

Krämer (1967) like most scholars before him, ignores the question of an 'original' hymn, and also tackles the problem of the text as presented in 1:3-14.

For him 'der einheitliche Mittelpunkt des ganzen Segensgeschehens' (a statement taken from Schlier 1958:40 note 2) with regard to the form and content of the

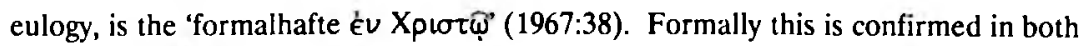
the opening $\dot{\epsilon} v$ formula and ending $\dot{\epsilon} v$ formula. From this it is obvious that the sentence endings 'überhaupt ein besonderes Gewicht zukommt' (1967:38).

However, two év formulas deserve special attention:

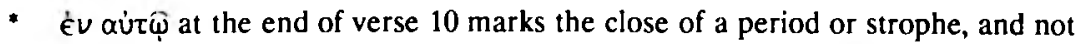
the beginning of a new section as indicated for instance by Nestle (and followed inter alia by Schnackenburg 1977 and Louw 1987). For Krämer it serves as epexegetical apposition to the preceding phrase 'all things in Christ', in which the phrase 'all things' is explained or expanded in the phrase 'which are in heaven and on earth'. 'Ev ourt $\widehat{\varphi}$ thus serves as focal or emphatical repetition of $\dot{\epsilon} \nu \mathrm{X} \boldsymbol{\rho} \iota \tau \hat{\varphi}$.

- The same applies to $\dot{\epsilon} \nu \dot{\alpha} \gamma \dot{\alpha} \operatorname{rn}$ at the close of verse 4. To place this phrase as the opening statement of another strophe or section (as Schnackenburg 1977 and Louw 1987 also do), is contrary to the hymnic style. 'Ev áyórtn can easily be perceived as 'Nachtrag' (1967:40) to $\dot{\epsilon} \xi \in \lambda \dot{\epsilon} \xi \alpha \tau o$ '...wobei es durch die Nachholung und Endsteliung im Kolon einen besonderen Ton empfängt...' (1967:40). Regarding both form and content it is related to the closing phrase

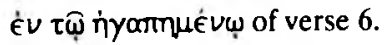

The following structure has been put forward by Krämer: 
I Benedictus formula 1:3

II Body:

Parts:

a. $4-6$

b. $7-10$

c. $11-12$

III Conclusion: $1: 13-14$.

Most scholars recognise verse 3 as the introduction. However, both Schattenmann (1965:2) and Roberts (1983:16) propose a break in verse 3. Apart from the fact that it forms a closely knit unity, two important aspects, the typical hymnic relative-style

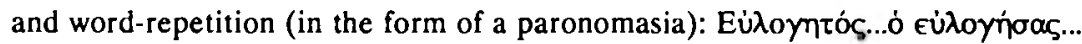

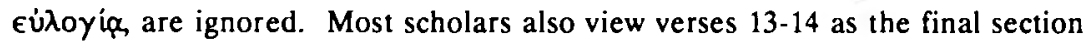
('epilogue'), because of the change from the 'we' style to the 'you' style, a change which marks it as a transitional passage (the receivers of the letter are addressed and reminded that they also share in these blessings of God - Schnackenburg 1977:85-87). It is, however, the middle section, verses $4-12$, on which scholars have differed in their reconstructions. Krämer divides this middle section (4-12) into three sub-sections on the following principles:

- Each sub-section consists of a sequence marked by a relative pronoun or $\dot{\epsilon} v$ phrase, a main verb, an aorist participle, and prepositional phrases (with kortó and $\epsilon$ is).

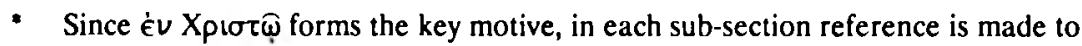

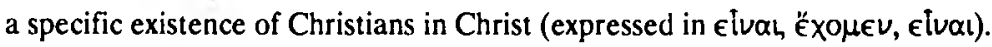

Looking at the reconstruction of Krämer, one again notices the problem with the long second section, although Krämer does try to avoid the difficulty by dividing it into three sub-sections, which gives the impression of symmetrical balance. However, the problem with the doxological phrase (refrain) remains. In his structure it comes at the close of section IIa and IIc, and III. Its position at the close of Ila seems awkward and unaccounted for.

\subsection{Lang: Second exponent of the formulaic theory}

In some preliminary and general remarks Lang (1969) acknowledges the existence of several hymnic markers, such as participle and relative phrases, as well as the liturgical formula $\epsilon$ l̆ ěratvov, but he rejects the dividing function of the participles and the liturgical phrase in this eulogy (Lang 1969:9). This is a logical conclusion seeing that he follows Krämer's 'sprachliche' analysis very closely (Lang 1969:note 17). 
Lang also judges the benediction formula of 1:3 of paramount importance. Following the pattern of the eulogy (God is first praised in the third-person style, then the reason for this praise follows), the author adds the key motive or focal phrase év Xpırţ̣. Verses 4-14 are thus 'eine theologische Entfaltung' (Lang 1969: 10) of this eulogy. For Lang, a significant change of style occurs from verse 11ff: Whereas the grammatical subject in 4-10 has been God, in 11 it becomes 'we' and 'you'. 'This implies a break in the passage, which Lang marks off as the beginning of the second strophe. From this it follows that the eulogy is divided into:
A. The benediction
$1: 3$
B. First strophe
$1: 4-10$
C. Second strophe
1:11-14.

Sections $B$ and $C$ serve as an expansion of the benediction. Within $B$ and $C$ we find the recurrence of the $\dot{\epsilon} v$ formula at the beginning and end of phrases which serve to divide each section into two sub-sections: B (4-10): (a) 4-6); (b) 7-10. C (11-14): (a) 11-12; (b) 13-14. The function of this év formula is seen not only as strophic

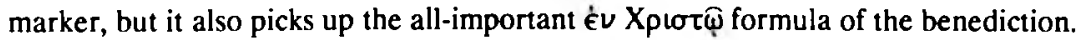
Within these sub-strophes Lang follows Krämer in identifying a clearly defined sequence of main verb, participle, and prepositional phrases. They are:

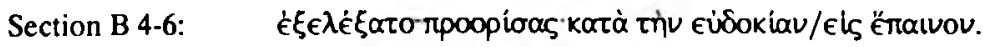

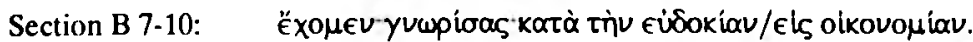

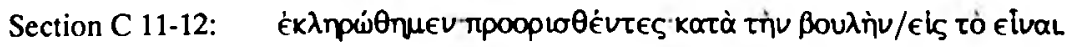

Lang (1969:11) observes in this connection: 'All dies ist nicht bloss Zufall, sondern bewusst gestaltete Form, wenn auch nicht in streng metrischer Bindung'.

As to section C, in which the 'you' leads 'zu den angeredeten Briefempfängern', a structural parallelism has been noted by several scholars (Ochel 1934; Schlier 1958; Masson 1953). Both are introduced by év $\bar{\psi}$ kai. Here we also find the sequence of main verb, participle phrase and prepositional phrase, but in the second sub-section the double participle has a disturbing effect. The change in 13 from 'we' to you' and then back to 'we' in 14 also constitutes a problem for Lang. He writes:

Dieser Wechsel und das grammatische Anakoluth erfordern eine Erklärung....Am besten lässt sich dieser tatbestand m.E. durch die Annahme verständlich machen, dass der Briefschreiber ein ursprüngliches 'Wir' der Eulogie, das den Stil der lobpreisenden Gemeinde 
kennzeichnet, zum Zweck der Ueberleitung auf die Leser in den Ihr-

Stil umgesetzt hat und dabei nicht konsequent verfahren ist.

(Lang 1969:11-12)

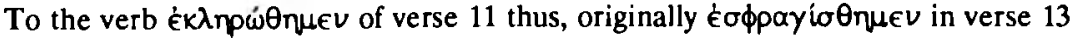

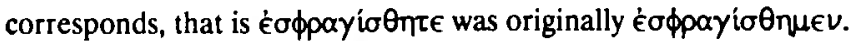

The double use of $\dot{\epsilon} \cup \bar{\psi} \mathrm{Kal}$ also reveals, according to Lang, the hand of the author. In reconstructing the eulogy he thus erases the second occurrence of this formula and transforms verse 13 to its 'original' sequence:

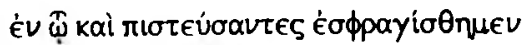

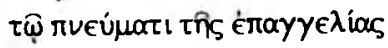

As the final result Lang presents the following structure:

A. Benediction formula 1:3

$=$ Praise of God for his blessings in Christ

B. First strophe 1:4-10

$=$ the adoption act of God in Christ

a. $4-6$

b. $7-10$

C. Second strophe 1:11-14

$=$ God's salvific act in Christ as baptismal gift to the congregation

a. $11-12$

b. 13-14.

The asymmetrical relation of $\mathrm{B}$ to $\mathrm{C}$, the rejection of the doxological phrase els Ëraw 13, are points that argue against this division. Regarding the function given to the

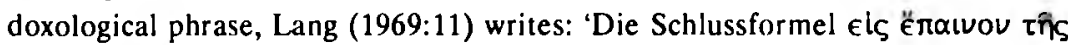

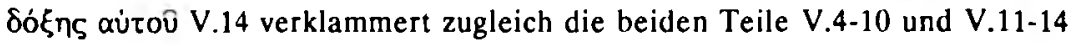
jeweils gegen Ende der ersten Halbstrophe V.6 und V.12'. This is not clear nor is it convincing. While verses 11 and 13 are introduced by the same formula, the change from 'we' to 'you' does not occur in 11. From the very beginning the author uses the 'we' style. It is only at 13 that the change really occurs. For this reason almost all scholars have linked 13-14, not 11-14. In my final discussion of the various principles of the strophic system, I will return to the participle phrases, which both 
Krämer and Lang to my mind erroneously reject as the dividing principle in this particular eulogy!

\subsection{Coutts: Reconstructing the 'original' hymn}

Coutts $(1956 / 7)$ is almost unique among scholars in his reconstruction of the 'original' hymn. His comparative study (relating Eph 1:3-14 to $1 \mathrm{Pt}$ 1:3-12, both being originally related to a baptismal liturgy) and ingenious reconstruction (although this will always remain speculative) deserves discussion.

Coutts fully recognises the dividing function of the phrase els Ĕratvou tîs $\delta o ́ \xi n s$ at 6, 12 and 14, as well as traces of a further formula in 5 and 11 (the katóphrases), with a displaced reminiscence of this formula in 9 . He also endorses the trinitarian principle as basic to the thought sequence of the eulogy. But it is in his reconstruction that Coutts's contribution mainly lies. To effectuate an 'original' hymn, the following procedure has been followed:

a. Five short phrases are omitted for various reasons (for these reasons the reader is referred to Coutts's article):

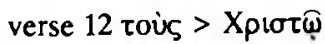

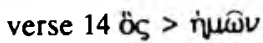

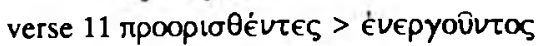

verse 11 €is tò €lvaı ñuâs

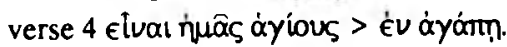

b. Some grammatical changes are necessary, changing for example $k \alpha \theta \dot{\omega} \varsigma$

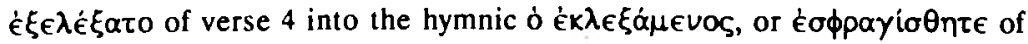
verse 13 to $\dot{\varepsilon} \sigma \phi \rho$ yír $\theta$ nev. In this case the reader is also advised to study these changes more closely in Coutts (1957:12-123). His reconstruction in Greek is given at the end of this paper in the appendix, to which the reader is referred in my following evaluation.

Given the fact that any endeavour to reconstruct the hymns or hymnic fragments in the New Testament, especially into its 'original' form, is of a speculative nature, the reconstruction of Coutts is nothing but ingenious for several reasons:

- The vexing problem of the relation of the length of the second strophe to the first and third strophes (the usual division of this eulogy), is avoided by a completely symmetrical balance of three strophes with 6 lines each, the refrain comprising lines 5-6 of each strophe. 
- This refrain consists of two lines with an identical pattern, which Coutts based on both the doxological phrase of 6,12 and 14 and the formula of 5,9 and 11 .

- There is also a thematic symmetry: each strophe corresponds neatly to one of the divine persons of the Holy Trinity, and although in my own analysis I have not taken this as dividing principle, the concept of the Trinity is clearly present in the eulogy.

* This reconstruction finally integrates the participle and prepositional phrases within the hymnic style.

\subsection{Schnackenburg: The linguistic theory}

One of the most profound studies on the Ephesian eulogy has been undertaken by Schnackenburg (1977). Although he saw the study of Krämer only after his own analysis had been made, in many respects he agreed with Krämer. Like Krämer his approach is a formal division of the text, but then he follows a linguistic approach by analysing the text '...unter syntaktischen, semantischen und pragmatischen Aspekte...' (1977:69). The principle of content ('die Ausdrucks- und Bedeutungsebene' 1977:68) is thus subordinated to the linguistic principle ('Nach den neueren linguistischen Erkenntnissen wird man von der sprachlich-formalen Analyze ausgehen müssen' 1977:68). For our purposes only the first category (the syntactic analysis) is of importance.

As point of departure, Schnackenburg refers to those formal elements that occur repeatedly in the passage, namely the forms $k \alpha \theta \dot{\omega} \zeta-k \alpha \tau \alpha$ ( $(4,5 b, 7 c, 9 b)$ coupled with three expressions indicating purpose: a final infinitive sentence in verse 4 , and the eic-expressions in $6,8,10,12$ and 14 . He refers to this as a 'sprachliche Bewegung' (Schnackenburg 1977:74), which cannot be accidental. These syntactic forms have the function of reflexion and explanation of the preceding participial statements. This syntactic scheme introduces a 'Sprachbewegung' comprising pauses followed by new statements leading again to pauses, et cetera. In the words of Schnackenburg (1977:75): 'In seiner auf die Segnung durch Gott ausgerichteten Reflexion legt der Verfasser kurze Besinnungspausen ein, um sogleich aufgrund des schon Gesagten und in Drang, noch mehr zu sagen, wieder neu aufzuheben und seine Reflexion weiterzu-führen'.

In the last section (verses 13-14) we find no $k \alpha \tau \alpha$-form, but a double stated purpose, both introduced by els.

In this 'Sprachbewegung' he identifies as transitions (pauses and new

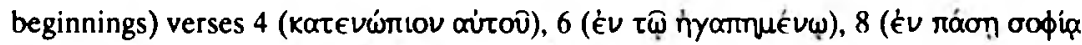

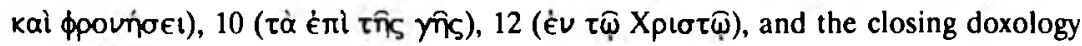

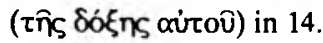


Schnackenburg (1977:73-74) accordingly identifies six 'Sprachbewegungen' with the following syntactic pattern as basis:

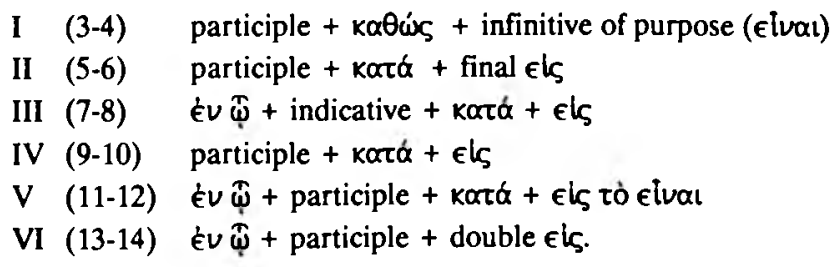

Schnackenburg explicitly avoids the term strophe and his concept of 'Sprachbewegungen' corresponds to Robbins's concept of 'periods' (see below).

\subsection{Robbins: The rhetorical theory}

A completely different approach has recently been taken by Robbins (1986), following his article on the structure of the hymn in Philippians 2:6-11 (Robbins 1980). In both these articles Robbins pleads for a rhetorically based approach. Referring to the dilemma scholars have faced since Norden [1913](1956), as a result of the length and awkwardness of Ephesians 1:3-14, Robbins (1986:677) ascribes this dilemma to 'an inadequate understanding of the nature of ancient Greek composition'. Robbins has in mind the principles of Greek rhetoric as explained by the Greek rhetoricians and exemplified in Greek literature, especially the principles involving periodic structure. According to this principle a lengthy Greek sentence breaks up into smaller units (cola), the ideal period normally consisting of four cola, each having more or less the length of a hexameter. The basic concept behind the period is that one should be able to pronounce it with a single breath. The sentence of Ephesians 1:3-14 is divided accordingly into eight periods. According to this principle Robbins presents the following rhetorical structure:
A. verse 3
$=5$ cola
B. verse 4
$=5$ cola
C. verses 5-6
$=5$ cola
D. verses $7-8$
$=6$ cola
E. verses $9-10$
$=5$ cola
F. verse 13
$=5$ cola
G. verse 14
$=3$ cola . 
One has the impression that Robbins (1986:687) is not adverse to the idea that a prayer or hymn forms the basis of the eulogy, but states nevertheless that '...similar structures are found in other parts of the NT that are not hymns or prayers....The form is better explained in terms of classical composition'. What is of immediate importance is that the refrain in each of its occurrences concludes a specific period (C, F and H), just as it does in the structure of Schnackenburg (II, V and VI).

\section{THE STROPHIC STRUCTURE OF EPHESIANS 1:3-14}

As indicated above, it is not possible to present in the compass of one article all the views on this passage. The reader is therefore advised to study especially the views of such scholars as Masson (1953), O'Brien (1979), Deichgräber (1967), Schille (1965), Maurer (1951/2), and Dahl (1951). An excellent bibliography up to 1963 is provided by Cambier (1963:59 note 3).

Before presenting the reader with the present author's reconstruction in Greek, some remarks concerning the formal principles involved in establishing the strophic structure of the eulogy, should be put forward:

- I judge the refrain to be of paramount importance and am in complete disagreement with the studies of Sanders, Krämer, and Lang regarding this vital strophic principle. The refrain has gradually become the most important strophic marker in the Christian hymn, and by no means at all should it be disregarded in those hymnic passages in which it does occur, as for example in the case of Ephesians 1:3-14 (see in this regard also Barkhuizen 1989a:12-13; Stander 1989a:209-214; 1989b:104-105). Sanders's (1965:226) criticism that the

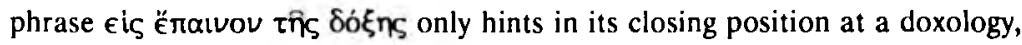
and not in its occurrence in verses 6 and 12, and that it can therefore not serve as dividing principle, is not convincing; and it in fact reveals an inadequate understanding of the function of the refrain in hymns profane or Christian. The fact is, however, that the phrase does form a doxology in each case, as Schnackenburg (1977:78-79) has recognised, although he unfortunately does not apply it in his formal or syntactical analysis. But even if it were not doxological in the other two occurrences, this is no valid objection: In many hymns from the fifth century onwards the refrain can vary in its nature and syntactical form. Thus the fact that in Ephesians 1:3-14 it does not follow the exact verbal or syntactical pattern is no valid argument against its function as such in this instance or any other.

- The prepositional phrases with év mark both the beginning and the ending of 
strophes: as opening formula in 7,11 , and 13 ; as closing formula in 4,8 , and 10 . In this way the opening and ending of strophes result in the same formal structure. Again, Sanders's (1965: note 52) argument, that in 13b év đิ does not refer to Christ, as in the other cases, but to the Gospel, fails to discredit the purely formal function of év (see also Schnackenburg 1977:75), which many scholars adopt as the dividing principle (e g Dibelius 1962:59; Krämer 1967:38ff; Lang 1969:10; Richter 1970 - the latter in connection with the Logos hymn in the Gospel of John). Schnackenburg (1977:76-77), however, also displaces the

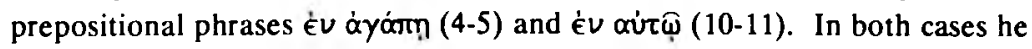
ignores the obvious structural pattern of the passage as a whole: rpoopiras at the beginning of 5 , corresponds to $\gamma v \omega$ pi $\alpha_{\alpha} \alpha_{\varsigma}$ at the beginning of 9 , while the placement of $\dot{\epsilon} v \alpha \dot{v} \tau \bar{\psi}$ at the beginning of 11 disturbs the balance and correspondance between it and 13 (both begin with $\dot{\epsilon} \mathcal{\Psi}$ kai). This identical formula is just too obvious to be ignored.

- The participial phrases in 5 and 9, already indicated as strophic markers by Coppieters (1909) and confirmed by Dibelius (1953), Maurer (1951/2), Käsemann (1958), Schille (1965), Gnilka (1971), and Schnackenburg (1977), serve to introduce in each instance a new section. In this regard both Krämer and Lang erroneously reject this principle in this hymn, although they recognise it as strophic principle in other instances!

- I have also taken the relative pronoun in 14 as a typical hymnic strophic marker. For its use as strophic marker one shoule also compare the hymns of Philippians 2:6-11 and Colossians 1:15-20, as well as in many post-biblical hymns. Verses 13 and 14 therefore each comprise a strophe, contra Schnackenburg (1977:74).

- Regarding the principle of content, I have deviated from the trinitarian concept as dividing principle, and have rather identified various thematic motives expressive of the main theme (the praise of God for all his blessings), each section containing a specific or dominant motive. These motives are listed below, in Section 4.1, before the Greek text of the eulogy.

One of the main problems with many of the existing reconstructions concerns the long section usually taken to comprise the 'second' strophe (verses 7-12), as Bouwman (1974:26) has already indicated. This is a result of all those reconstructions that divide the passage into three sections, based on the trinitarian concept. In this regard one should recognise the fact that the trinitarian concept may be seen as an obstacle and it should therefore not be applied in too rigid a manner (see Coutts 1956/7:117). And, although it is without doubt present in this eulogy, I have therefore not taken it as a dividing principle, as already indicated 
above.

Whether we refer to this passage as 'Kunstprosa' or poetry, it is clear that the passage is a deliberately stylised introduction to the letter as a whole. It is also irrelevant whether we call the sections into which it is usually divided 'Sprachbewegungen', periods, strophes or merely sections. In my own reconstruction of this eulogy, taking all the above-mentioned principles of form and content into account, I have followed the structural concept put forward by Watson (1986), taken on his part from Haüblein, The Stanza, quoted by Watson (1986:160). According to this concept the stanza forms the main divisive element within a poem/hymn, the strophe the main divisive element within a stanza, and the verse the main divisive element within a strophe. Watson compares this internal relation with that of a house (stanza), of which the rooms (strophes) form the smaller units, and the furniture (verses) in the room the smallest units. One may of course object that stanza and strophe are used in many works as synonyms, yet the idea of a larger unit in which smaller units form a unity, each larger unit being concluded with a refrain (as proposed below for Eph 1:3-14), can be confirmed and verified by two famous

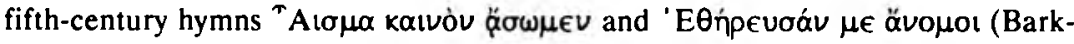
huizen 1989b:175-190). The concept of verses within a strophe, and strophes within a stanza, is convenient, and for this reason I have adopted this terminology of Watson, but, as indicated above, this principle or idea is present in the two hymns which I have referred to. I maintain that it is really irrelevant what terminology one uses. It is the principle which is of importance. It is also interesting to note that in the first of these hymns the refrain does not follow the same syntactical form throughout the hymn either!

In accordance with this principle I have divided the eulogy as follows:

$\begin{array}{ll}\text { Stanza } 1= & \text { strophe } 1 \text { (verse } 3) \\ & \text { strophe } 2(\text { verse } 4) \\ & \text { strophe } 3(\text { verses } 5-6) \\ \text { Stanza } 2= & \text { strophe } 1 \text { (verses } 7-8) \\ & \text { strophe } 2(\text { verses } 9-10) \\ & \text { strophe } 3(\text { verses } 11-12) \\ \text { Stanza } 3 & \text { strophe } 1 \text { (verse } 13) \\ & \text { strophe } 2(\text { verse } 14) .\end{array}$

Each stanza (or larger unit) is concluded by the refrain, the refrains marking off the stanzas as more or less of equal length, while both the formal elements and the principle of content are fully taken into account. Strophe 1 of stanza 1 forms the 
prooimion or introitus, while stanza 3, being one strophe shorter than stanza 1 and 2 , forms both the epilogue of the eulogy and the transitional passage to the rest of the letter.

In is also interesting to note that in the analysis of Robbins, based on Greek rhetorical composition, and according to which the passage is divided into eight periods, these periods correspond almost verbally with the eight strophes or smaller units of my proposed structure. This confirms the rhetorical equality of the proposed strophes, that is the strophes correspond to the rhetorical periods of Greek rhetorical composition.

\section{RECONSTRUCTION OF THE EULOGY IN EPHESIANS 1:3-14}

\subsection{Theme and motives}

Theme (stanza 1: strophe 1 = 1.1): Praise of God for all his spiritual blessings in Jesus Christ.

This theme is subsequently expressed and explained by various motives, each strophe dominated by a specific motive. They are:

1. The motive of election (1.2)

2. The motive of adoption as children (1.3)

3. The motive of deliverance and forgiveness of sins (2.1)

4. The motive of the unity of all things in Christ (2.2)

5. The motive of sharing in his inheritance (2.3)

6. The motive of the Holy Spirit as seal (3.1)

7. The motive of the Holy Spirit as pledge of our inheritance and deliverance (3.2).

\subsection{The Greek Text}

STANZA 1

Strophe 1 (Prooimion)

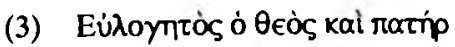

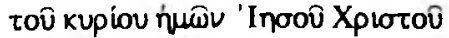

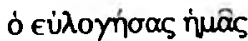

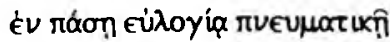

év toîs éroupaviols év Xploț̂. 
Strophe 2

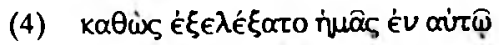

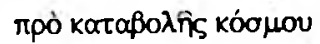

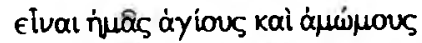

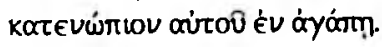

Strophe 3

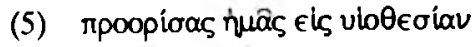

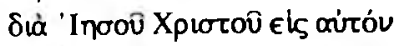

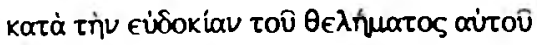

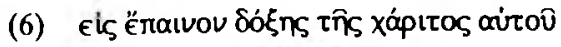

nุ

\section{STANZA 2}

Strophe 1

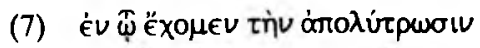

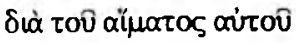

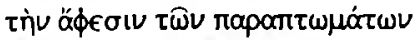

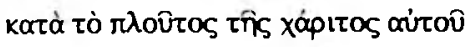

(8) त̂

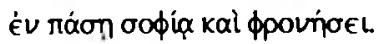

Strophe 2

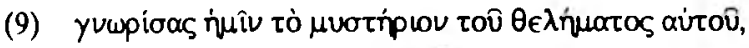

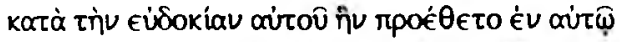

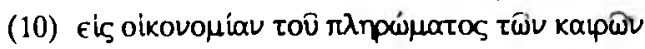

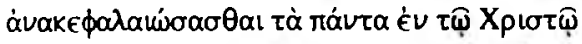

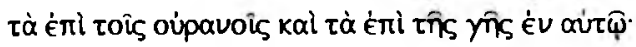

Strophe 3

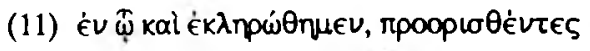

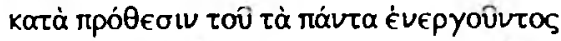

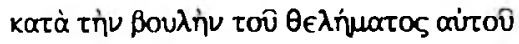




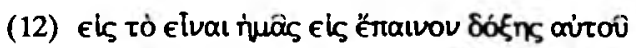

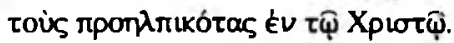

STANZA 3

Strophe 1

(13) Ev đ̣̂ kal ùjueis

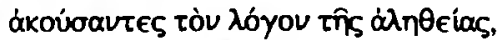

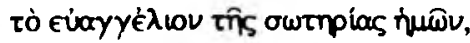

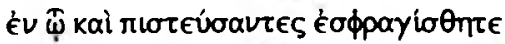

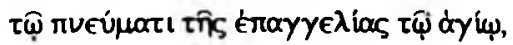

Strophe 2

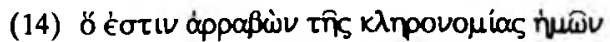

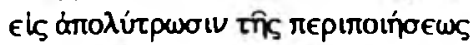

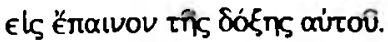

\section{CONCLUSION}

In the course of this article I have remarked several times that any reconstruction of this passage is speculative, yet I believe that such an attempt is not without any significance for the interpretation of the letter as a whole. As O'Brien (1979) has indicated, this is an unusual introduction to the letter, and it is therefore necessary to take a closer look at both its form and function. The aim of this paper was not to discuss its function within the context of the letter as a whole, but only to analyse its formal characteristics and structure. There can be little doubt that 1:3-14 is a deliberately stylised passage and the recognition of the fact that it follows the hymnic genre of the eulogy gives the proper perspective on the letter: God is praised in an extensive and expanded form for his blessings in Jesus Christ. Thus the author appropriately prepares the readers for the main themes of his letter.

In my analysis I have taken into account (a) the formal characteristics of hymnic texts (the eulogy falls within the genre of hymnic texts), limiting the importance of (b) the trinitarian concept as a dividing a principle, rather concentrating on (c) the concept of theme and motives. I believe I have limited the problems of form and structure since my proposed reconstruction corresponds with both the principles of Greek rhetorical composition and the strophic division of existing examples of early hymns. The result is, to my mind, a more symmetrical structure, and one in which 
each section and sub-section becomes expressive of the theme of the eulogy in the form of various theological motives.

\section{APPENDIX}

\section{The model of Coutts}

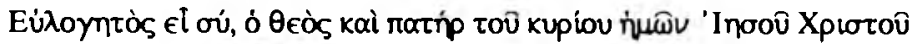

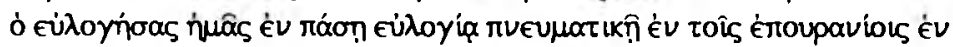

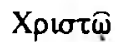

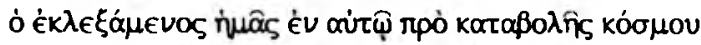

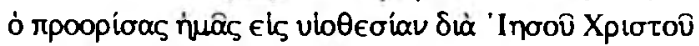

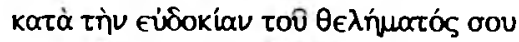

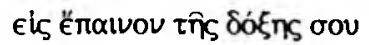

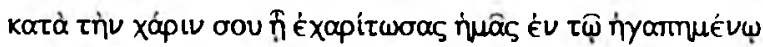

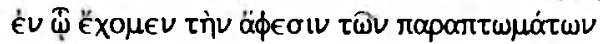

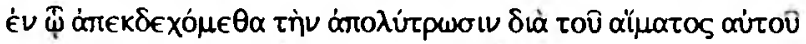

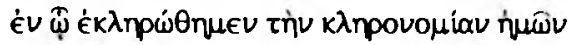

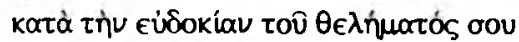

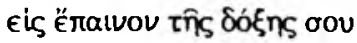

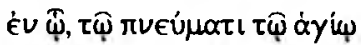

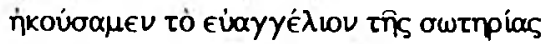

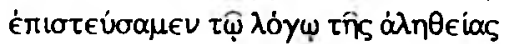

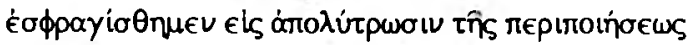

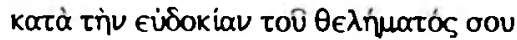

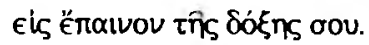

2. The model of Schnackenburg

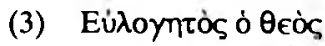

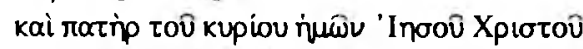

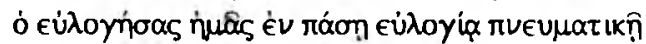

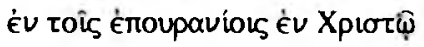




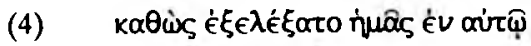

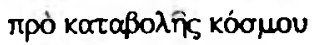

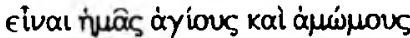

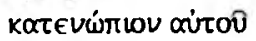

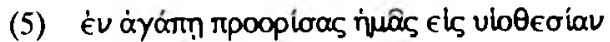

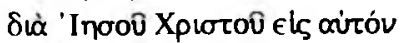

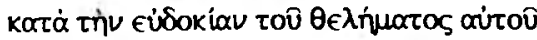

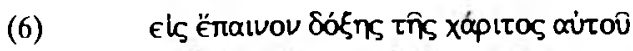

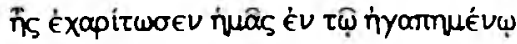

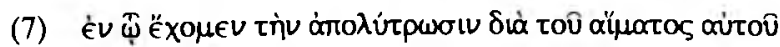

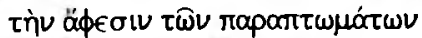

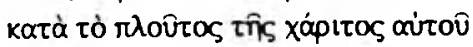

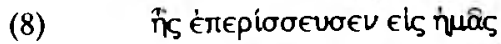

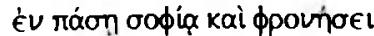

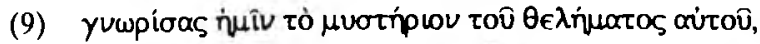

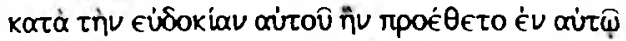

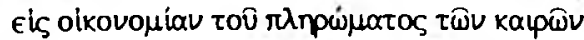

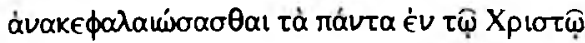

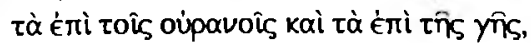

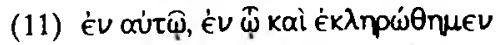

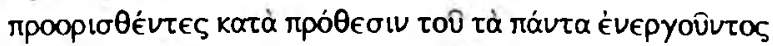

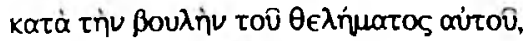

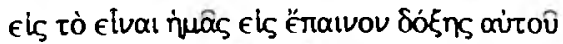

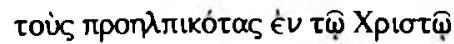

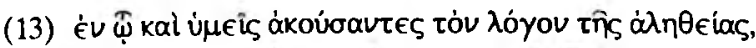

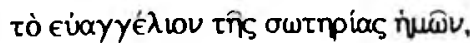

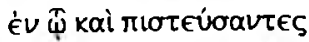

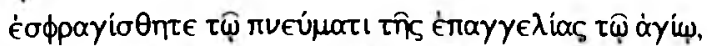

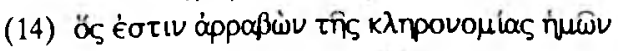

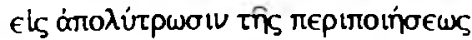

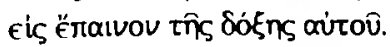


3. The model of Robbins

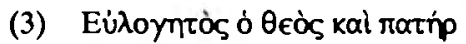

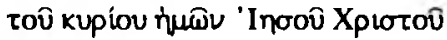
ò eìoynoas nuâs

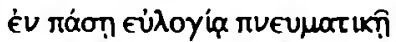

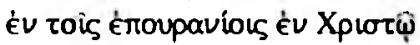

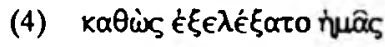
Év $\alpha \dot{\alpha} \tau \bar{\varphi}$

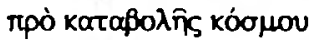

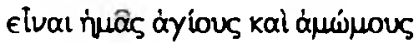

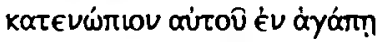

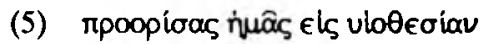

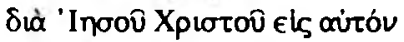

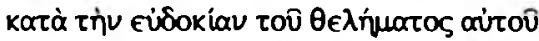

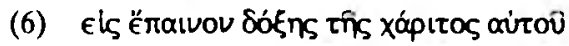
ñs éxapi

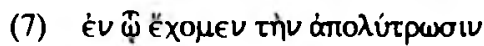

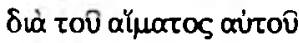

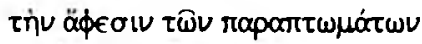

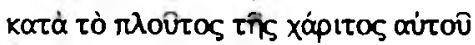

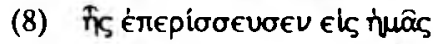

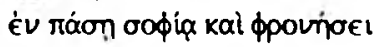

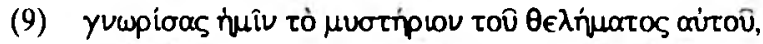

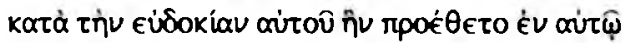

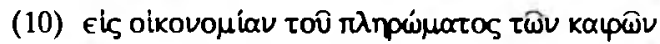

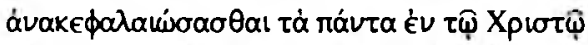

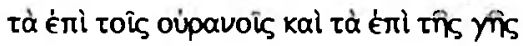

(11) $\dot{\epsilon} v \alpha \dot{v} \tau \bar{\varphi}$

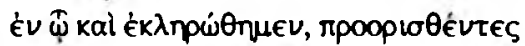

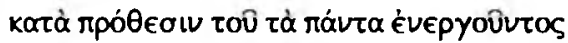

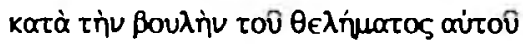




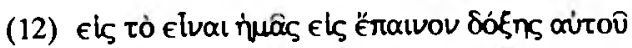

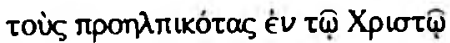

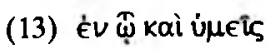

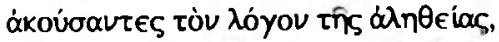

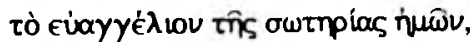

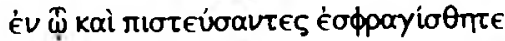

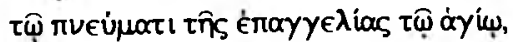

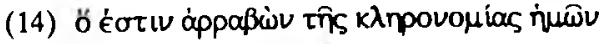

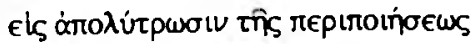

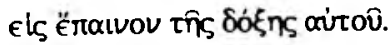

Works cited

Audet, J-P 1958. Esquisse historique du genre litteraire de la 'Bénédiction' juive et de L'Eucharistie' chrétienne (1). RB 65, 371-399.

Barkhuizen, J H (red) 1989a. Hymni Christiani. Pretoria: Gutenberg. (HTS Suppl 1.)

..- 1989b. Inleiding, in Barkhuizen 1989a:9-14.

... 1989c. Vroeë strofiese himnes, in Barkhuizen 1989a:175-190.

Bouwman, G 1974. De Brief aan de Efeziers: Het Nieuwe Testament. Bussum: Unieboek.

Cambier, J 1963. La bénédiction d'Eph 1,3-14. ZNW 54, 58-104.

Conzelmann, H 1976. Die Briefe an die Galater, Epheser, Philipper, Kolosser, Thessalonicher und Philemon. Göttingen: Vandenhoeck.

Coppieters, H 1909. La doxologie de la lettre aux Ephesiens: Notes sur la construction syntaxique de Eph.1,3-14. RB 6, 74-88.

Coutts, J 1956/7. Ephesians 1:3-14 and 1 Peter 1:3-12. NTS 3, 115-127.

Dahl, N A 1951. Afresse und Proömium des Epheserbriefes. ThZ 7, 241-264.

Deichgräber, R 1967. Gotteshymnus und Christushymnus in der frühen Christenheit: Untersuchungen zu Form, Sprache und Stil der frühchristlichen Hymnen. Göttingen: Vandenhoeck.

Dibelius, M 1953. An die Kolosser, Epheser, an Philemon. Tübingen: Mohr. (HNT.) Gloer, W H 1984. Homologies and hymns in the New Testament: Form, content and criteria for identification. Perspectives on Religious Studies 11, 115-132.

Gnilka, J 1971. Die Epheserbrief. Freiburg: Herder.

Innitzer, T H 1904. Der Hymnus im Epheserbrief, 1:3-14. ZKTh 28, 612-621.

Käsemann, E 1958. sv Epheserbrief. RGG II. 
Kråmer, H 1967. Zur sprachliche Form der Eulogie Eph.1, 3-14. Wort und Dienst 9, 34-46.

Lang, F 1969. Die Eulogie in Epheser 1,3-14, in Abramowski, L \& Goeters, J F (eds), Studien zur Geschichte und Theologie der Reformation. Neukirchen Verlag.

Louw, J P 1987. Ephesians 1:3-14: A liturgical hymn? Unpublished lecture, University of Pretoria.

--- 1989. Die Johannese Logos-himne (Joh 1:1-18), in Barkhuizen 1989a:35-43.

Maier, J 1972. Geschichte der judischen Religion. Berlin: De Gruyter.

Martin, R P 1982. sv Hymns in the NT. The International Standard Bible Encyclopedia II.

-.- 1983. New Testament hymns: Background and development. ET 94/ 95, $132-$ 136.

Masson, CH 1953. L'épitre de saint Paul aux Galates: L'épitre de saint Paul aux éphesiens. Commentaire du Nouveau Testament. Paris: Neuchâtel.

Maurer, C 1951/2. Der Hymnus von Eph 1 als Schlüssel zum ganzen Brief. EvTh $11,151-172$.

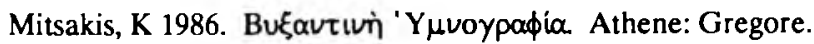

Norden, E [1913] 1956. Agnostos Theos: Untersuchungen zur Formgeschichte religiöser Rede. Stuttgart: Teubner.

O'Brien, P 1979. Ephesians 1: An unusual introduction to a New Testament letter. NTS 25, 504-516.

Ochel, W 1934. Die Annahme einer Bearbeitung des Kolosserbriefes im Epheser-Brief. Ev.-teol. Diss.: Marburg.

Richter, G 1970. Ist (en) ein strukturbildendes Element im Logoshymnus Joh 1,1ff? Biblia 51, 539-544.

Robbins, Ch J 1980. The rhetorical structure of Philippians 2:6-11. CBQ 42, 73-82.

--- 1986. The composition of Ephesians 1:3-14. JBL 105/4, 677-687.

Roberts, J H 1983. Die Brief aan die Efesiërs. Kaapstad: NG Kerkuitgewers.

Robinson, J M 1964. Die Hodajot-Formel in Gebet und Hymnus des Frühchristentums. BZNW 30, 194-235.

Sanders, J T 1965. Hymnic elements in Ephesians 1-3. ZNW 56 (3-4), 214-232.

Schattenmann, J 1965. Studien zum neutestamentlichen Prosahymnus. München: Beck'sche.

Schille, G 1965. Frühchristlichen Hymnen. Berlin: Evangelische Verlagsanstalt.

Schlier, H 1971. Der Brief an die Epheser. Düsseldorf: Patmos.

Schnackenburg, R 1977. Die grosse Eulogie Eph 1,3-14: Analyse unter textlinguistischen Aspekten. $B Z$ 21, 67-87. 
Stander, H F 1989a. The Starhymn in the Epistle of Ignatius to the Ephesians (19:23). VigChr 43, 209-214.

Stander, H F 1989b. Ignatius. Christus die Ster: Aan die Efesiërs 19,2-3, in Barkhuizen 1989a:102-106.

Van der Lugt, P 1980. Strofische structuren in de Bijbels-Hebreeuwse Poëzie. Kampen: Kok.

Watson, W G E 1986. Classical Hebrew poetry: A guide to its techniques. Sheffield: JSOT. 